\title{
AKTIVITAS MAKAN LARVA IKAN KAKAP MERAH, Lutjanus argentimaculatus PADA SISTEM PEMELIHARAAN DENGAN PENGGUNAAN CAHAYA BUATAN
}

\author{
Regina Melianawati
}

\begin{abstract}
ABSTRAK
Cahaya merupakan faktor yang berperanan penting dalam aktivitas makan larva. Penelitian ini bertujuan untuk mengetahui aktivitas makan larva ikan kakap merah, $L$. argentimaculatus yang dipelihara dengan pemberian cahaya buatan secara berkesinambungan. Pemeliharaan larva dilakukan dalam ruangan dengan menggunakan tangki poliethylene volume $500 \mathrm{~L}$. Intensitas cahaya di permukaan media diatur sebesar 800 lux. Pengambilan sampel dilakukan pada larva $\mathrm{D}-5, \mathrm{D}-10, \mathrm{D}-15$, dan D-20. Hasil analisis pembedahan lambung menunjukkan bahwa aktivitas makan larva berlangsung selama 24 jam, namun aktivitas yang maksimal terjadi pada pukul 10.00-14.00. Rata-rata jumlah pakan alami yang terdapat dalam lambung larva D-5, D-10, D15 , dan D-20, masing-masing adalah $2,09 \pm 1,17 ; 4,45 \pm 1,30 ; 19,61 \pm 13,74$; dan $27,94 \pm 6,46$ individu. Jumlah pemangsaan larva berkorelasi dengan pertumbuhan larva itu sendiri yang dinyatakan dengan persamaan $y=4,7498 x-9,4584\left(R^{2}=0,9017\right)$
\end{abstract}

ABSTRACT: Feeding activity of mangrove snapper Lutjanus argentimaculatus larvae reared in artificial lighting system. By: Regina Melianawati

Light intensity was an important factor in feeding activity of larvae. This research was aimed to know feeding activity of mangrove snapper larvae Lutjanus argentimaculatus that reared in artificial lighting condition. Larval rearing was done indoor used polyethylene tank $500 \mathrm{~L}$ volume. Light intensity in water surface was arranged to 800 lux. Samples were taken from $D-5, D-10, D-15$, and D-20 larvae. The stomach surgical analysis showed that feeding activity of mangrove snapper larvae was occurred during 24 hours, but maximum feeding activity was at 10.00 a.m. until 14.00 p.m. The average numbers of life feeds found in $D-5, D-10, D-15$, and $D-20$ larvae stomach were $2.09 \pm 1.17,4.45 \pm 1.30,19.61 \pm 13.74$, and $27.94 \pm 6.46$ individual, respectively. The number of larvae feeding correlated with the growth of larvae by equation $y=4.7498 x-9.4584\left(R^{2}=0.9017\right)$.

KEYWORDS: feeding, light intensity, larvae, mangrove snapper

\section{PENDAHULUAN}

Kakap merah merupakan jenis ikan demersal, yang umumnya mendiami perairan berdasar keras (Nasution, 1993). Namun kakap merah muda sering dijumpai menempati perairan hutan bakau atau di daerah yang banyak ditumbuhi rumput laut (Anonim, 1992). Daerah penyebarannya di wilayah Indonesia meliputi perairan Sumatera, Jawa, Nusa Tenggara, Kalimantan, Sulawesi (kecuali di laut dalam sebelah Utara Sulawesi), Irian Jaya (kecuali palung Laut Banda), dan Maluku (Anonim, 1987).

Harga ikan ini cukup baik di pasar dunia, meskipun masih di bawah harga ikan kerapu. Di pasar Hongkong harga grosirnya mencapai US $\$ 5,5$, sedangkan harga ecerannya mencapai US\$18,1 (Sugama \& Priono, 2003). Kondisi ini berdampak pada usaha penangkapan yang meningkat dari tahun ke tahun untuk mengikuti permintaan pasar. Bahkan Indonesia dan Australia akan mengembangkan teknik penangkapan ikan kakap merah ini di laut lepas dengan menggunakan metode pemantauan pola arus, tinggi gelombang, temperatur laut, sebaran klorofil, dan arah angin sehingga para nelayan Australia diharapkan mampu menjaring 95\% ikan kakap merah dalam sekali penangkapan. Namun demikian, cara tersebut dapat mengandung risiko kelangkaan populasi jenis ikan ini akibat over fishing (Soesilo \& Budiman, 2002).

Untuk membatasi kegiatan penangkapan yang berlebih maka usaha pembenihan ikan kakap merah ini perlu dikembangkan. Menurut Kinnie (1977), keberhasilan pembenihan sangat dipengaruhi oleh berhasil tidaknya larva mengambil pakan (exogenous energy) pada awal pemangsaan. Di lain pihak jadwal penyediaan pakan harus didukung dengan tersedianya data tentang pola makan harian (diurnal feeding) yang terkait dengan peningkatan daya penglihatan dan 
kemampuan memangsa (Barahona \& Fernandes, 1979), karena pada umumnya aktivitas makan larva ikan laut sangat bergantung pada cahaya (Tandler \& Mason, 1982). Adanya intensitas cahaya optimum selama malam hari akan meningkatkan kemampuan penglihatan larva sehingga dapat menunjang keberhasilan larva dalam aktivitas pencarian pakan dan pemangsaan (Astuti et al., 2000).

Penelitian ini bertujuan untuk mengetahui aktivitas makan larva ikan kakap merah, L. argentimaculatus yang dipelihara pada sistem dengan penggunaan cahaya buatan.

\section{BAHAN DAN METODE}

Pengamatan dilakukan di Laboratorium Penelitian Balai Besar Riset Perikanan Budidaya Laut (BBRPBL), Gondol-Bali pada tahun 2003. Larva yang digunakan untuk pengamatan berasal dari telur hasil pemijahan alami induk kakap merah, $L$. argentimaculatus yang dipelihara dalam sebuah tangki beton kapasitas $100 \mathrm{~m}^{3}$ dengan sistem sirkulasi yang diberi pakan berupa ikan rucah dan cumi.

Telur hasil pemijahan induk akan terbawa aliran air permukaan keluar melalui sebuah saluran dan selanjutnya akan terkumpul dalam tempat penampung telur yang berada di sisi luar tangki induk. Di bagian dalam tempat penampung telur tersebut dipasang saringan pengumpul telur (egg collector). Telur yang terkumpul dalam egg collector tersebut selanjutnya dipindahkan ke dalam fiberglass volume $200 \mathrm{~L}$ untuk diseleksi antara yang fertil dan yang infertil. Telur yang fertil selanjutnya diinkubasi dengan sistem air mengalir dalam tangki inkubator. Larva hasil tetasannya kemudian dipindahkan ke dalam tangki pemeliharaan larva dan dipelihara untuk pengamatan.

Pemeliharaan larva dilakukan dalam tangki yang bervolume $500 \mathrm{~L}$ terbuat dari bahan polyethylene berwarna hitam pada seluruh bagiannya. Tangki tersebut ditempatkan dalam ruangan (indoor) dengan menggunakan sistem resirkulasi sesuai metode Billund Aquaculture (Steenfeldt et al., 2002). Pergantian air diatur sebesar $400 \%$ per hari dan dilakukan mulai hari kelima masa pemeliharaan.

Pencahayaan buatan yang digunakan untuk masing-masing tangki pemeliharaan larva berasal dari dua buah lampu TL-40 watt dan satu buah lampu halogen 100 watt yang masing-masing tergantung setinggi $108 \mathrm{~cm}$ dan $75,5 \mathrm{~cm}$ dari permukaan air. Intensitas cahaya di permukaan air tersebut diatur sebesar 800 lux dan pencahayaan ini dilakukan secara berkesinambungan selama 24 jam.

Pakan alami yang digunakan terdiri atas rotifer (Brachionus sp.), copepod (Tisbe holothuriae), dan artemia. Rotifera diberikan mulai hari kedua dengan kepadatan 10 ind. $/ \mathrm{mL}$. Pemberian rotifera ini kemudian meningkat hingga kepadatan antara $15-30$ ind $/ \mathrm{mL}$ setelah larva mencapai umur 10 hari ke atas Pemberiannya dilakukan tiga kali dalam sehari, yaitu pada pagi, siang, dan malam hari. Copepod mulai diberikan pada hari keempat dengan kepadatan 2 ind./ $\mathrm{mL}$. Artemia diberikan pada hari kelima belas dengan kepadatan 2 ind. $/ \mathrm{mL}$. Ke dalam media pemeliharaan larva ditambahkan pula Nannochloropsis sp. Penambahan fitoplankton tersebut dilakukan bersamaan dengan waktu pemberian pakan alami. Pakan buatan komersial mulai diberikan secara bertahap pada hari ke dua belas.

Pengamatan dilakukan pada umur larva D-5, D10, D-15, dan D-20. Pengambilan sampel larva dilakukan setiap interval 2 jam dalam kurun waktu 24 jam pada umur yang diamati. Jumlah sampel setiap waktu pengamatan sebanyak 10 ekor larva. Sampel larva tersebut diambil secara hati-hati dengan menggunakan pipet plastik yang bermulut lebar, selanjutnya diletakkan pada object glass dan dilakukan pembedahan pada lambungnya. Pengamatan tersebut dilakukan dengan menggunakan mikroskop stereoskopis.

Parameter yang diamati meliputi pola makan larva serta jumlah dan jenis masing-masing pakan alami yang terdapat dalam lambung larva pada setiap waktu pengamatan. Parameter lain yang dianalisis adalah nilai sukses pemangsaan (feeding incidence). Sukses pemangsaan merupakan nilai yang menunjukkan sejauh mana populasi larva sukses untuk mendapatkan pakan (feeding incidence $=100 \%$, berarti seluruh populasi larva sukses melakukan pemangsaan). Nilai hasil pengamatan yang ditampilkan merupakan nilai rata-rata. Data suhu air dalam media pemeliharaan larva dicatat setiap kali pengambilan sampel larva.

\section{HASIL DAN BAHASAN}

Hasil penelitian menunjukkan bahwa nilai sukses pemangsaan pada larva ikan kakap merah, umur D5 cenderung berfluktuasi, di mana pada pukul 08.00 baru $50 \%$ dari sampel larva yang sukses melakukan aktivitas makan, lalu pada siang hari nilai sukses pemangsaannya meningkat hingga $100 \%$ dan mulai menunjukkan penurunan secara terus menerus mulai pukul 16.00 hingga pukul 20.00 (Gambar 1). Berfluktuasinya nilai sukses pemangsaan larva selama periode waktu tersebut menunjukkan bahwa aktivitas makan larva D-5 tersebut cenderung masih mengikuti pola pemangsaannya yang terjadi secara alami. Pada larva ikan kakap merah yang dipelihara dengan kondisi pencahayaan alami, terlihat bahwa 


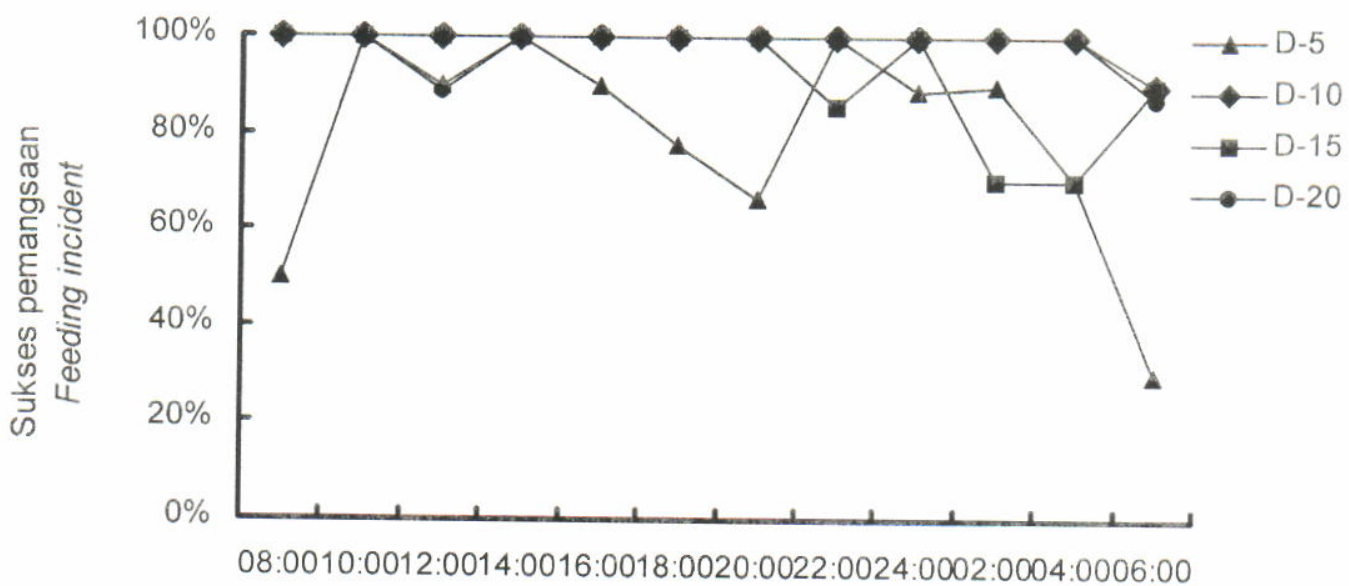

Waktu (Time)

Gambar 1. Nilai sukses pemangsaan larva ikan kakap merah, L. argentimaculatus pada sistem pemeliharaan dengan pencahayaan buatan

Figure 1. Feeding incident of mangrove snapper larvae, L argentimaculatus in rearing system with artificial lighting

pola pemangsaannya mengikuti kondisi pencahayaan yang ada, di mana aktivitas pengambilan pakan dimulai pada saat telah terdapat cahaya matahari dan diakhiri pada saat pencahayaan sudah tidak ada (Melianawati et al., 2001).

Namun demikian nilai sukses pemangsaan pada larva ikan kakap merah D-5 kembali memperlihatkan adanya peningkatan pada pembedahan lambung larva pukul 22.00. Hal ini menunjukkan bahwa populasi larva D-5 kembali melakukan aktivitas makan setelah dilakukan pemberian pakan sekitar pukul 20.00 . Dengan demikian nampak adanya respon dari larva tersebut terhadap pakan alami yang diberikan. Dari hasil tersebut terlihat bahwa aktivitas makan larva dapat dipacu dengan pemberian cahaya buatan pada malam hari.

Larva ikan kerapu macan (Epinephelus fuscoguttatus) yang dipelihara dengan sistem pemeliharaan yang sama, yaitu dengan pemberian pencahayaan selama 24 jam, juga menunjukkan nilai sukses pemangsaan yang masih berfluktuasi pada larva D-5.

Pada larva ikan kakap merah D-10, D-15, dan D20 terlihat bahwa nilai sukses pemangsaan cenderung stabil, yaitu hampir $100 \%$ selama periode 24 jam. Kestabilan larva yang cenderung terus melakukan pemangsaan tersebut menunjukkan bahwa larva telah mampu beradaptasi dengan kondisi lingkungan hidupnya yang diberi pencahayaan buatan selama 24 jam.

Sukses pemangsaan larva berdampak pada pola pemangsaannya. Pada larva D-5, D-10, D-15, dan D20 terlihat bahwa aktivitas makan larva berlangsung secara terus-menerus dengan adanya pemberian pencahayaan buatan (Gambar 2). Dengan demikian nampak bahwa pemberian pencahayaan buatan berpengaruh positif terhadap aktivitas makan larva, di mana larva dapat melakukan aktivitas makan secara terus-menerus selama adanya pencahayaan

Namun demikian pola pemangsaan larva yang alami juga masih nampak yaitu dengan kecenderungan peningkatan jumlah pakan yang terdapat dalam lambung larva mulai dari pagi hingga siang hari dan kecenderungan penurunan jumlahnya mulai sore hingga keesokan paginya. Jumlah pakan alami yang paling banyak ditemukan dalam lambung larva adalah pada siang hari, sedangkan penurunan jumlah pakan alami dalam lambung larva mulai nampak pada pukul 14.00 dan 16.00

Rata-rata jumlah pakan alami yang terdapat dalam lambung larva ikan kakap merah D-5, D-10, D-15, dan D-20, masing-masing adalah $2,09 \pm 1,17 ; 4,45 \pm 1,30$; $19,61 \pm 13,74$; dan $27,94 \pm 6,46$ individu. Dari data tersebut nampak bahwa jumlah pakan alami dalam lambung larva meningkat seiring dengan peningkatan umur larva.

Jumlah pakan alami dalam lambung larva meningkat dengan sangat tajam mulai pada larva D15. Hal ini diduga berhubungan erat dengan pertumbuhan larva itu sendiri, di mana pada larva D15 tersebut telah tumbuh sirip punggung dan sirip perutnya. Hal ini memungkinkan larva untuk bergerak secara lebih aktif sehingga larva memerlukan pasokan energi yang lebih banyak yang diperoleh dari pakannya. 


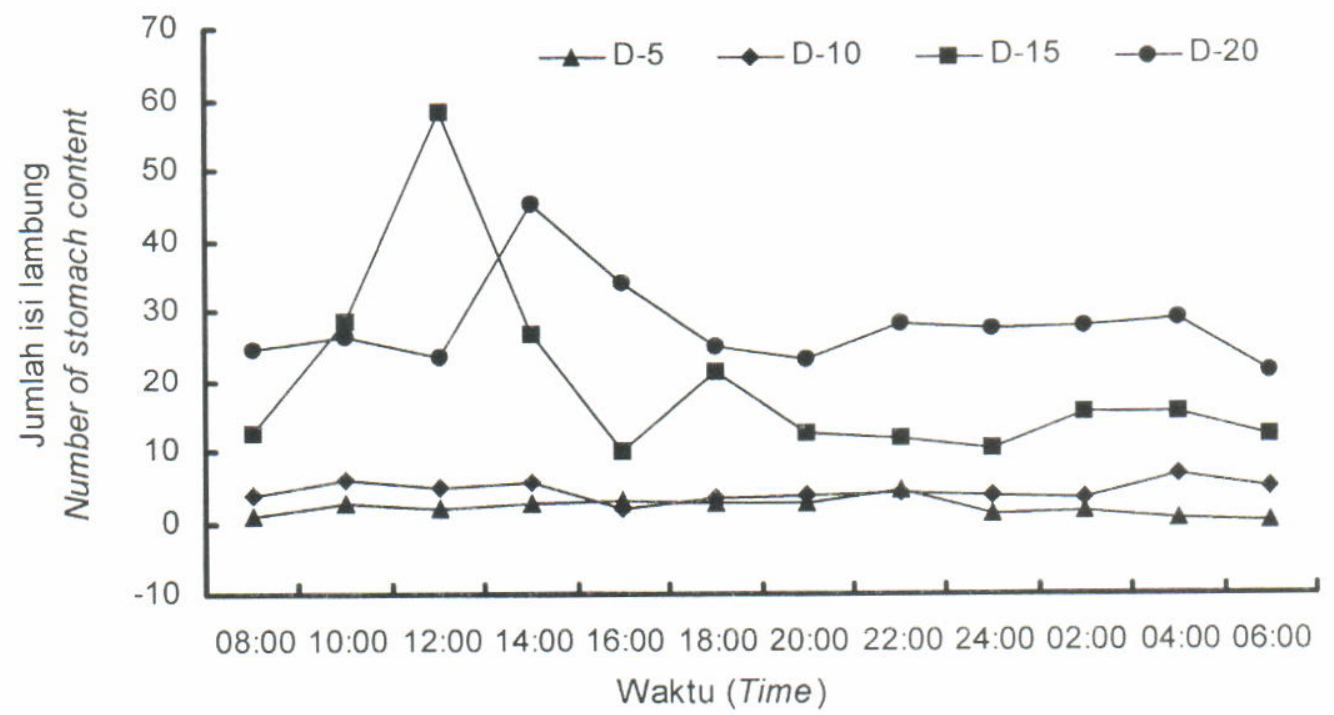

Gambar 2. Pola pemangsaan larva ikan kakap merah pada sistem pemeliharaan dengan pencahayaan buatan Figure 2. Feeding pattern of mangrove snapper larvae L. argentimaculatus in rearing system with artificial lighting

Pada larva D-20 terlihat bahwa rata-rata jumlah pakan alami dalam lambung pada seluruh sampel yang diamati kembali menunjukkan peningkatan dibandingkan dengan pada larva D-15. Hal ini disebabkan pada umur tersebut larva mengalami pertumbuhan yang pesat dan juga berada dalam fase metamorfosis dari bentuk larva menjadi bentuk yuwana sehingga membutuhkan pasokan jumlah energi yang lebih banyak lagi.

Jenis pakan alami yang terdapat dalam lambung larva ikan kakap merah mulai dari awal pemangsaan sampai dengan D-15 adalah sama yaitu terdiri dari rotifer dan copepod, sedangkan artemia baru ditemukan pada larva D-20 karena jenis pakan alami tersebut memang baru diberikan setelah larva berumur lebih dari 15 hari. Komposisi masing-masing jenis pakan alami yang ditemukan dalam lambung larva adalah $93 \%$ rotifer dan $7 \%$ copepod pada larva D-5, sedangkan pada larva D-10 adalah $63 \%$ rotifer dan $37 \%$ copepod. Pada larva D-15 komposisinya hampir sama yaitu $55 \%$ rotifer dan $45 \%$ copepod. Pada larva D-20 terjadi perubahan komposisi dengan adanya pemberian tambahan jenis pakan alami artemia, sehingga komposisinya menjadi $0 \%$ rotifer, $16 \%$ copepod, dan $84 \%$ artemia. Dari data tersebut terlihat bahwa komposisi isi lambung larva didominasi oleh rotifer pada awal pemangsaan namun seiring dengan perkembangan umur larva komposisi yang dominan mulai bergeser kepada jenis pakan alami yang lain yaitu copepod dan kemudian artemia (Gambar 3).

Mulai dari D-5 sampai dengan D-15, nampak copepod lebih mendominasi isi lambung larva pada malam hari. Hal ini mungkin disebabkan sifat copepod yang lebih pasif dan menempel pada bagian dinding tangki sehingga menyebabkan larva lebih mudah untuk memangsanya dalam kondisi di mana secara alami larva biasanya sudah tidak melakukan pemangsaan lagi. Oleh karena sifatnya yang menempel maka keberadaannya cenderung dapat bertahan lebih lama dalam media pemeliharaan karena tidak terpengaruh pada sirkulasi air. Di samping itu, ketersediaan rotifer sendiri diduga sudah mulai berkurang pada periode waktu tersebut.

Hubungan antara jumlah isi lambung dan pertumbuhan larva mengikuti persamaan $y=4,7498 x-$ 9,4584 dengan $R^{2}=0,9017$ (Gambar 4). Hal ini menunjukkan bahwa jumlah isi lambung larva berhubungan dengan peningkatan umur dan pertumbuhan larva itu sendiri.

\section{KESIMPULAN}

* Dengan adanya pemberian cahaya buatan selama 24 jam maka aktivitas makan larva ikan kakap merah, $L$. argentimaculatus dapat berlangsung secara terus-menerus selama periode pencahayaan tersebut.

* Jumlah pakan alami dalam lambung larva meningkat seiring dengan peningkatan umur larva.

\section{UCAPAN TERIMA KASIH}

Dengan selesainya penelitian ini disampaikan terima kasih kepada Sdr. Katimin dan Asep, teknisi BBRPBL, Gondol atas bantuannya selama pelaksanaan penelitian ini. 

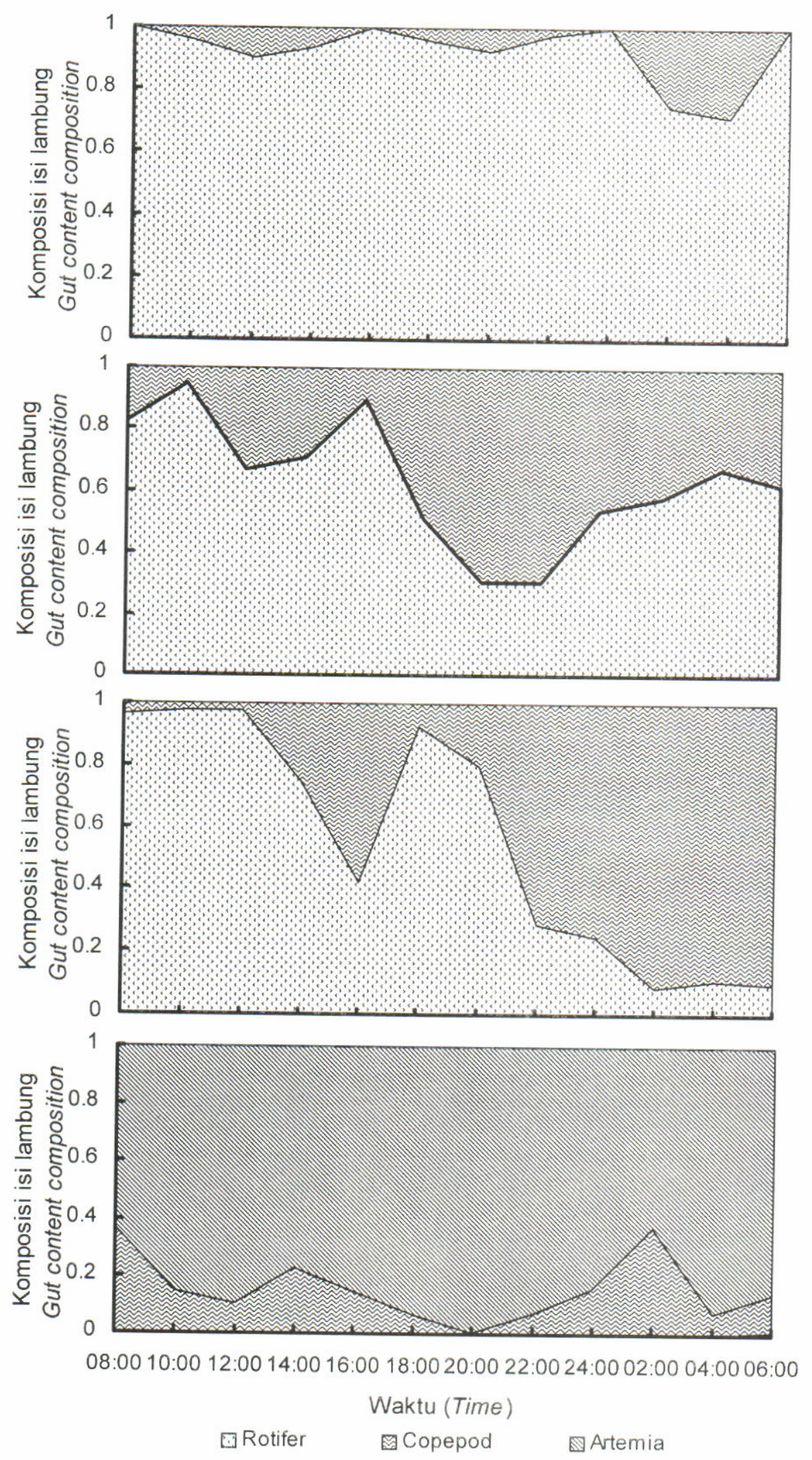

Gambar 3. Komposisi jenis pakan alami dalam lambung larva ikan kakap merah, L. argentimaculatus pada sistem pemeliharaan dengan pencahayaan buatan

Figure 3. Composition of life feed of mangrove snapper larvae, L. argentimaculatus in rearing system with artificial lighting 


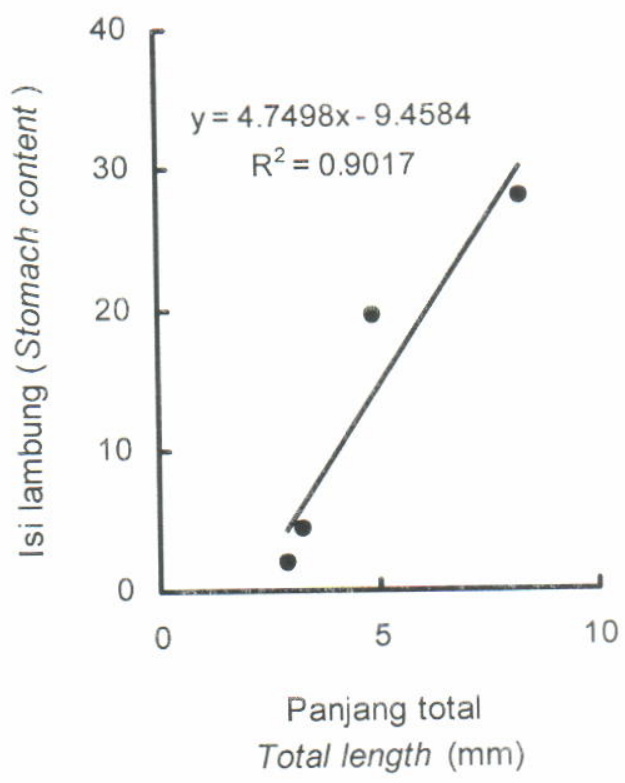

Gambar 4. Hubungan antara jumlah pakan alami dalam lambung dengan panjang total larva ikan kakap merah, L. argentimaculatus pada sistem pemeliharaan dengan pencahayaan buatan

Figure 4. Relationship between number of life feeds in stomach and total length of mangrove snapper larvae L. argentimaculatus in rearing system with artificial lighting

\section{DAFTAR PUSTAKA}

Anonim. 1987. Penyebaran Beberapa Sumber Perikanan di Indonesia. Direktorat Bina Sumber Hayati. Direktorat Jenderal Perikanan, Deptan. Jakarta.

Anonim. 1992. Penelitian, penyebaran dan kelimpahan induk ikan (kakap, kerapu) untuk menunjang budidaya (domestika dan aquaculture). Sub Balitkanlut Semarang dalam Laporan hasil penelitian Sub Balitkanlut Semarang.

Astuti, H., B. Hanggono, R. Widaningroem, dan Kamiso. 2000. Intensitas cahaya, pengaruhnya terhadap pertumbuhan dan laju sintasan larva kerapu tikus (Cromileptes altivelis). Jurnal Perikanan UGM II (2): $41-47$.

Barahona, M.H. dan Fernandes. 1979. Some effect of light intensity and photoperiod on the seabass larvae (Dicentranrchus labrax) reared at the cre oceanologique de Bretague. Potugal. Aquaculture, 17: $311-321$.

Kinnie, O. 1977. Marine Ecology, a Comprehensive, Interfrated Treatise on Life in Oceaous and Costal Waters. John Wiley and Son. Chichester. New York. Brisbane. Toronto. Volume III, part 2.
Melianawati, R. P.T. Imanto, M. Suastika, dan J.H Hutapea. 2001. Pola pemangsaan larva ikan kakap merah (Lutjanus sp.) menunjang managemen pemeliharaan larva. Laporan Teknis Proyek Inventarisasi dan Evaluasi Potensi Sumberdaya Kelautan Gondol-Bali Tahun Anggaran 2001, 18 pp.

Nasution, C. 1993. Kalipo, suatu rawai dasar untuk penangkapan ikan demersal di perairan berdasar keras. Prosiding Simposium Perikanan I. Badan Litbang Perikanan, Ispikani, Himapikani, JICA.

Soesilo, I. dan Budiman. 2002. Jurus menangkap kakap merah. Dalam Iptek untuk Laut Indonesia. LISPI. Jakarta, p. 92-94.

Steenfeldt, S., P.B. Pedersen, A. Jokumsen, and I. Lund. 2002. Hatchery production of tropical marine fish in recirculation systems. Training Course. Danish Institute for Fisheries Research. Denmark, 103 pp.

Sugama, K. dan B. Priono. 2003. Pengembangan budidaya ikan kerapu di Indonesia. Warta Penelitian Perikanan Indonesia edisi Akuakultur, 9(3): 20-22.

Tandler, A. and C. Mason. 1982. Light and food density effects on growth and survival of larvae Gilthead Seabream (Sparus aurata, Linnaeus, Sparidae). J. World Mariculture Sco., 14: 103-109. 